\title{
Empowering global leaders through workplace sustainability: A case of Zambian leaders
}

\begin{tabular}{|c|c|}
\hline $\begin{array}{l}\text { Authors: } \\
\text { Robert Daugh } \\
\text { Maja Zelihic } \\
\text { Chera Deresa } \\
\text { Hellicy C. Nga' } \\
\text { David Ssekam }\end{array}$ & $\begin{array}{l}\operatorname{erty}^{1} \text { (1) } \\
\text { (1) } \\
\mathrm{mbi}^{2,3} \text { (1) } \\
\mathrm{atte}^{4,5} \text { (1) }\end{array}$ \\
\hline $\begin{array}{l}\text { Affiliations: } \\
\text { }{ }^{2} \text { Department } \\
\text { Management, } \\
\text { Advanced Mar } \\
\text { Studies, Forbe } \\
\text { Business and T } \\
\text { Ashford Unive } \\
\text { Diego, CA, The } \\
\text { States of Amer }\end{array}$ & $\begin{array}{l}\text { f Business } \\
\text { Faculty of } \\
\text { nagement } \\
\text { s School of } \\
\text { rechnology, } \\
\text { rsity, San } \\
\text { United } \\
\text { rica }\end{array}$ \\
\hline $\begin{array}{l}{ }^{2} \text { Department } \\
\text { Management, } \\
\text { Business Studi } \\
\text { Mulungushi U } \\
\text { Kabwe, Zambi }\end{array}$ & $\begin{array}{l}\text { f Business } \\
\text { School of } \\
\text { es, } \\
\text { niversity, } \\
\text { a }\end{array}$ \\
\hline $\begin{array}{l}{ }^{3} \text { Department } \\
\text { Management, } \\
\text { Economics anc } \\
\text { Sciences, Univ } \\
\text { South Africa, P } \\
\text { South Africa }\end{array}$ & $\begin{array}{l}\text { f Business } \\
\text { College of } \\
\text { Management } \\
\text { ersity of } \\
\text { retoria, }\end{array}$ \\
\hline $\begin{array}{l}{ }^{4} \text { Department } \\
\text { Management, } \\
\text { Business and } \\
\text { Uganda Mana } \\
\text { Institute, Kam }\end{array}$ & $\begin{array}{l}\text { f Business } \\
\text { School of } \\
\text { Management, } \\
\text { gement } \\
\text { pala, Uganda }\end{array}$ \\
\hline $\begin{array}{l}{ }^{5} \text { Department } \\
\text { Management, } \\
\text { Education and } \\
\text { Sciences, Carl } \\
\text { University of C } \\
\text { Oldenburg, Ge }\end{array}$ & $\begin{array}{l}\text { ff } \\
\text { Faculty of } \\
\text { Social } \\
\text { von Ossietzky } \\
\text { Idenburg, } \\
\text { rdmany }\end{array}$ \\
\hline $\begin{array}{l}\text { Corresponding } \\
\text { David Ssekama } \\
\text { dmssekamatte }\end{array}$ & $\begin{array}{l}\text { g author: } \\
\text { atte, } \\
\text { @gmail.com }\end{array}$ \\
\hline $\begin{array}{l}\text { Dates: } \\
\text { Received: } 12 \mathrm{~J} \\
\text { Accepted: } 05 \mathrm{~J} \\
\text { Published: } 22 \mathrm{~J}\end{array}$ & $\begin{array}{l}\text { une } 2020 \\
\text { Vov. } 2020 \\
\text { Jan. } 2021\end{array}$ \\
\hline Read online: & \\
\hline 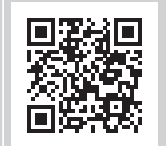 & $\begin{array}{l}\text { Scan this QR } \\
\text { code with your } \\
\text { smart phone or } \\
\text { mobile device } \\
\text { to read online. }\end{array}$ \\
\hline
\end{tabular}

Authors:

Chera Deresa ${ }^{2}$ (D)

Hellicy C. Nga'mbi ${ }^{2,3}$

Affiliations:

Department of Business

Advanced Management

Studies, Forbes School of

Business and Technology,

Ashford University, San

${ }^{2}$ Department of Busines

Kabwe, Zambia

${ }^{3}$ Department of Busines Management, College of Sciences, University of South Africa, Pretoria, Business and Management Uganda Management

${ }^{5}$ Department of

Management, Faculty of ducation and Social Sciences, Carl von Ossietzky University of Oldenburg,

Corresponding author: David Ssekamatte,

Dates:

Received: 12 June 2020 Accepted: 05 Nov. 2020 Published: 22 Jan. 2021

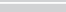

to read online.
The African continent is experiencing a significant economic development characterised by many challenges as its emerging 21st-century leadership is finding its own path. Forceful and often uneven integration into the global economic system causes many of the issues that many African nations face. The leadership gaps, gender inequality, bias and multigenerational workforce coupled with inherent lack of strong institutions capable of driving the development agenda in the continent remain an impediment to a full realisation of responsible, accountable, relevant and ethical (RARE) leadership. This article presented two Fulbright quantitative descriptive research projects, which were presented at Mulungushi University in Kabwe, Zambia. The first Fulbright project aimed at educating Zambian faculty and students on how to develop leadership skills appropriate for the 21stcentury workplace. The second one aimed at conducting a comprehensive assessment of the current Zambian leadership across 18 different industries. A mixed-methods approach was adopted for this study with a convergent parallel mixed-methods design. Data were collected using a survey questionnaire triangulated with focus group data from 246 Zambian leaders across 18 different industries. Quantitative data were analysed using descriptive statistics with the Statistical Package for Social Sciences (SPSS) software, whilst qualitative data were analysed by thematic analysis. The results revealed that Zambian leaders face challenges of lack of proper talent management and poor infrastructure, effective mentoring and human resource gaps. The findings also indicated that offsetting leadership gaps will require a focus on education, talent management, empowerment of women leaders and finding a unique African path of leadership. The findings of this study pointed to the need for Zambian industries to deal with leadership deficits so as to enhance workplace sustainability.

Keywords: RARE; empowering global leaders; workplace sustainability; the 21st century leadership skills; African leaders; bias.

\section{Introduction}

Two Fulbright projects were carried out in Zambia from June 2018 to April 2019. The purposes of the projects were twofold. The first Fulbright project aimed to educate Zambian faculty and students on how to develop the leadership skills the 21st-century workplace demands, with an understanding of the complexities, challenges and opportunities unique to the southern African region. Fulbright Specialists did not set out to share Western best practices with the audience. Instead, through sharing survey findings, they attempted to identify an effective path for leaders within Zambian societal and cultural frameworks, whilst reflecting on some comparable Western leadership experiences. The aim of the second Fulbright project was to conduct a comprehensive assessment of current Zambian leadership, with its full range of challenges and opportunities through research data gathered from the leaders of Zambia across 18 different industries.

The two Fulbright projects were completed at the Mulungushi University in Kabwe, Zambia. The first project took place in December 2018 and the second one was completed in April 2019. Mulungushi University is one of the three Zambian public universities established in 2008 and has six schools (faculties), which offer degrees, diplomas and certificates. Considering Mulungushi University's history of partnership with the Konkola copper mines and its excellent cooperation with Zambian businesses in both curriculum development and

How to cite this article: Daugherty R, Zelihic M, Deresa C, Nga'mbi HC, Ssekamatte D. Empowering global leaders through workplace sustainability: A case of Zambian leaders. J transdiscipl res S Afr. 2021;17(1), a897. https://doi.org/10.4102/td.v17i1.897

Copyright: ㄷ 2021. The Authors. Licensee: AOSIS. This work is licensed under the Creative Commons Attribution License. 
postgraduate career prospects for its students, it is imperative for this university to provide students and faculty with superb expertise in leadership studies. The first project consisted of researchers gathering data on comprehensive leadership survey findings from 246 participants, middle- and high-level Zambian leaders across different industries: business, agriculture, mining, manufacturing, education, government, retail and several other sectors. In December, Fulbright researchers gathered data, conducted analysis and made presentations at an executive leadership seminar with the theme Empowering global leaders in the 21st century. The second Fulbright project, Zambian path to workplace sustainability through efficient leadership, consisted of a series of lectures with Zambian students and a 2-day seminar with Zambian leaders, including two esteemed key speakers, Dr Ronald Msiska, Secretary to the Cabinet of the President of Zambia and Mr Chance Kabaghe, Chief Executive Officer (CEO) of Indaba Agricultural Policy Research Institute (IAPRI).

The Fulbright seminar exposed students, faculty and staff to the most current concepts within the field of global leadership, whilst focusing on some relevant topics impacting African business markets, particularly the southern African region. The leadership expertise provided by the Fulbright specialist facilitated the exchange of ideas, the incorporation of suggestions from other experts in the field, and the introduction of some of those concepts into Mulungushi University's future curriculum, which will enhance the responsible, accountable, relevant and ethical (RARE) value system embedded in its strategic plan.

The first Fulbright project involved the following: sharing of data gathered through a survey completed by Zambian leaders; analysis of emerging leadership theories within a framework of rapidly developing African economies, focusing on variables of change adaptability, implementation and complacency avoidance; and discussion on empowering female leaders whilst focusing on innovative approaches as participants addressed specific obstacles that women leaders encounter in the developing world. This segment highlighted the significant role of men in enhancing women's progress in all avenues of life, education arena and workplace in particular. Furthermore, the researchers and audience members analysed multigenerational workforce challenges, with a focus on unconscious bias at a 21st-century Zambian workplace. The participants agreed that as digital natives collide with digital immigrants at any workplace, it becomes imperative for business leaders to maintain the delicate balance of talent and technology capitalisation whilst ensuring the ideals of a harmonious relationship between employees. The project also included aspects of offsetting the leadership gap in the developing world through education, talent management, emerging technology utilisation (cloudbased technology) and adaptability to rapid change environment, and analysis of a unique African path to global leadership with a focus on its rich pre-colonial tradition. The audience agreed that African leaders should not mimic their Western counterparts but instead develop their unique styles properly positioned within their respective societies.

The second Fulbright project analysed the role the Zambian government should play in regulating some of the foreign companies entering the domestic market. The consensus was reached that locals standing to gain from market globalisation through stipulating multinational companies should hire a certain segment of the local force, regulating excessive land ownership by the foreign corporations, and training and hiring local managers. The project also explored ways to ensure female empowerment in all ranks of leadership, including but not limited to affirmative action methods, such as gender quotas, in cases of equal qualification and competence of two candidates of opposite gender. The participants identified the fields where women are under-represented, brainstorming ways to address this gap, whilst identifying roles the community should play in women's empowerment.

It also involved discussions of 'triple threat capability leadership' as advocated by Bill Boulding, Dean of Duke University: raw intelligence (IQ), emotional intelligence (EQ), 'decency quotient' (DQ) and cultural intelligence (CQ) in reference to its impact on the Zambian workplace and the unconscious bias in the workplace, which impacts all layers of Zambian business. ${ }^{1}$ The question was raised whether differences in age, gender and tribal affiliation are over-emphasised and whether those issues are obstacles to perceived workplace. There was also a discussion on the need to avoid a 'copy/paste' leadership approach under the assumption that African leaders should not pursue Western-style leadership. Zambian leaders need to create their unique leadership path fitting their culture, tradition, diversity and national pride.

The key research questions were as follows:

- Which set of variables can offset the leadership gap in Africa, and Zambia in particular?

- What particular resources do African leaders lack in order to offset the leadership gap?

- What are some specific challenges unique for African leaders, not shared by their global counterparts?

- How much of a challenge does a multigenerational workforce present to Zambian leadership?

- What are some of the challenges female Zambian leaders experience?

- What is the unique path Zambian leaders ought to take to be compatible with their global counterparts?

This article begins with the conceptual and theoretical framework adopted for the study and then presents the literature review on leadership in the African context, highlighting the key debates and issues that other researchers have raised regarding the nature of leadership styles and challenges of leadership on the continent. It explains the methodology followed and presents the key findings from the study, as well as the conclusion. 


\section{Literature review}

\section{Conceptual framework and theoretical framework}

For the purpose of this article, the researchers explored, amongst others, the concept of workplace sustainability. This concept refers to the balancing act of ensuring resources, human element and tools within the organisation are aligned to produce success and viability in the long term.

The study was informed by the theoretical framework on transformative leadership. In his seminal work Leadership 1978, James MacGregor Burns introduced the theory of transformational leadership (see Figure 1). ${ }^{2}$

Abazeed $^{3}$ argued that transformation leadership is a type of leadership that enhances 'the level of achievement and selfdevelopment' amongst groups of individuals and entities (p. 119). Transformational leaders are characterised by their ability to pursue the interest of their groups or entities over their own interest and can ably rally subordinates towards achievement of the entity objectives. As illustrated in Figure 1 , there are four key dimensions of transformation leadership: the first one is the idealised influence, which relates to the behaviour of the leader and how it inspires the subordinates to work towards achievement of the vision and mission of the entity. The behaviour of a transformative leader will enable him or her to get trust and respect from those below him or her, and therefore the ability to influence others towards achieving organisational goals. The second dimension is the inspirational motivation of the leader to rally others behind the vision, mission and objectives of the organisation. The transformative leader inspires others and shows enthusiasm to work towards achieving the

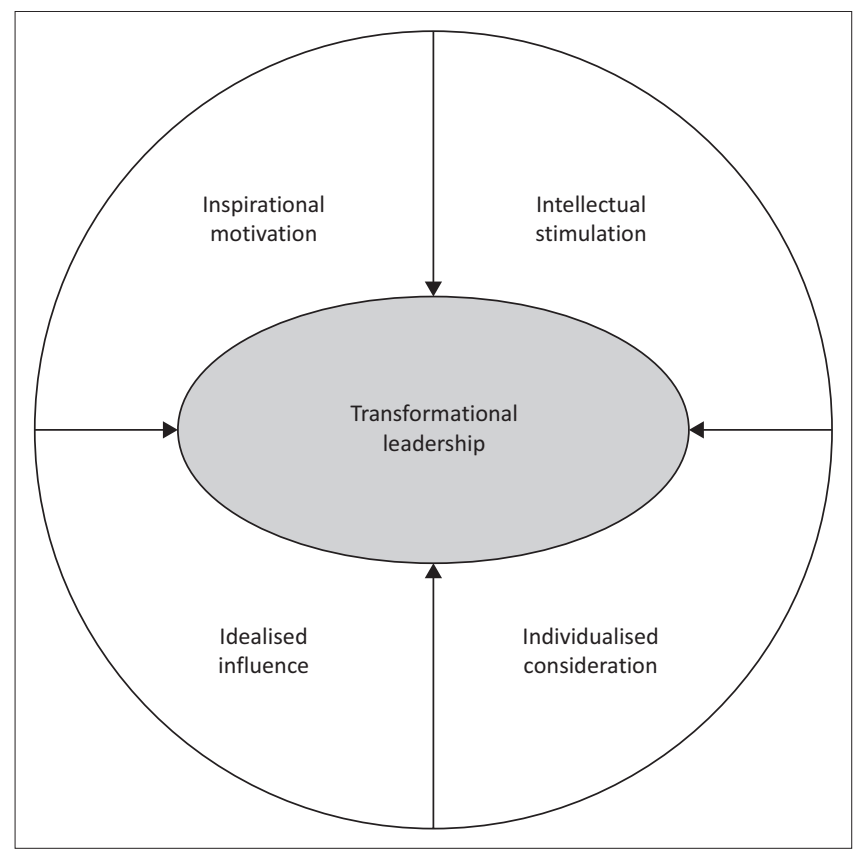

Source: Riva-Mossman S, Kampel T, Cohen C, Verloo H. The senior living lab: An example of nursing leadership. Clin Interv Aging. 2016;11:255-263. https://doi. org/10.2147/CIA.S97908 FIGURE 1: Transformational leadership. objectives of the organisation. The third dimension is the intellectual stimulation of the transformative leader, which involves the ability of the leader to think and act rationally and intelligently when leading others. A transformational leader will mobilise new ideas and inspire others to try them out. The fourth dimension is the individualised consideration, which relates to the ability of the leader to assess the needs of the individuals working under him or her and linking their priorities to the development of the organisation.

This theoretical framework was adopted to support the analysis of leadership gaps, the available resources to leaders and the challenges they face towards achieving transformative leadership and sustainability in Zambia. The dimensions of transformation leadership were used as indicators to measure variables that offset leadership gaps in the selected sectors in Zambia.

\section{Empirical perspectives on the leadership in the African context}

Research ventures have shown that transformational and adaptive styles of leadership are best equipped to handle the ever-changing business landscape in the southern African region. Ngambi ${ }^{4}$ stated that 'the African continent has a paradox of being one of the richest in natural resources and its diversity but one of the poorest in basically all aspects' (p. 70). Managing these vast national resources to foster economic growth and development, thereby alleviating poverty, is a crucial skill for Africa to master. ${ }^{5}$ Foreign direct investment increased for Africa from $\$ 30.5$ billion to $\$ 42.7 \mathrm{bn} .^{5}$ Considering the rapid growth of businesses and globalisation of the entire African continent, encouraging the production, dissemination and practice of management and leadership knowledge applicable to Africa cannot be overemphasised when it comes to the growth and development of its organisations and economies. Globalisation in Africa brings employment opportunities, higher living standards, foreign trade and more choices in both products and services to customers. Whilst Africa is developing rapidly, the leadership gap needs to be addressed in order to create empowered leaders who can address the challenges globalisation brings to a developing world.

Business leadership and management are the critical determinants of any undertaking and, subsequently, the entire economy. Donkor et al. $^{6}$ argued that the success of any business depends on how effective its leaders are' (p. 6). The effectiveness of the leaders will determine how inspired and motivated the employees of the firm will be and, therefore, how productive they will be. Today, business leaders must adopt sustainable leadership approaches if they are to lead and manage businesses in the 21st century in an effective manner. The authors argued that global business leaders should be able to take into consideration the complex and ever-changing global systems and how these relate to human values in undertaking their 
operations. Global-oriented leaders require a high level of flexibility in their leadership and management styles in addition to highly competitive skills required for global markets. Therefore, leaders need to be empowered to meet the required standards through both skills and resources.

Business leaders should be able to deal with the key challenges to businesses. In Africa, for example, George et al. ${ }^{7}$ reported that:

The greatest challenge to business stems from the persistence of institutional voids, understood as the absence of market supporting institutions, specialized intermediaries, contractenforcing mechanisms, and efficient transportation and communication networks. (p. 377)

These challenges require business leaders to ensure sustainable business performance and to tap into existing opportunities. Empowering global leaders will entail skilling them to be strategic thinkers, entrepreneurs and innovators, who are $\mathrm{RARE}^{8}$ and responsive managers, as well as to be effective knowledge managers in their firms and businesses.

Olalere $^{9}$ called for the adoption of a complexity leadership approach in Africa in order to deal with the leadership crisis. The author argued that 'complexity leadership is ideal for African nations because it can identify the various tensions inherent in the systems, the interactions, networks, pressures and conflicts' (p. 182). This kind of leadership promotes adaptability and flexibility amongst the leaders and managers of businesses to 'generate emergence and change' in business entities and, therefore, catalyse new and creative ideas. The leader, in this case, becomes a catalyst for learning and new ideas as well as creativity, which leads to sustainable business ventures. According to the author, the biggest challenge for the business leaders in Africa is the size of the complexity. In Africa, there are huge complex issues but a limited number of business leaders who are ready to handle the complex business environment on the continent.

$\mathrm{Nkomo}^{10}$ argued that management knowledge is vital to the development and transformation process in Africa. Business firms in Africa are yet to explore their capabilities through management knowledge, ensuring that their institutions are able to create, share, use and manage institutional knowledge in their operations. Firms in Africa could enhance their abilities to expand and boost their productivity if they deliberately adopted a systematic approach to developing a knowledge base in their organisations. Ultimately, knowledge promotes innovation in business firms, which subsequently stimulates growth.

Acquaah et al. ${ }^{5}$ decry the limited scientific literature on knowledge about management in Africa, especially by African authors. This gap in knowledge management on the continent illustrates a deficiency in the development of management capacity on the continent. The continent needs contextualised research and scholarship that will adequately support developing sustainable solutions to local issues.
Sustainability of businesses in any economy requires a high level of entrepreneurship and innovation by business leaders and managers. Donaldson et al. ${ }^{11}$ contends that 'entrepreneurship and innovation form the cornerstone of economic development in many developing countries' (p. 19). The authors explain that the role of entrepreneurs in any economy cannot be overemphasised, as entrepreneurs stimulate production, create jobs and supply consumption products and services that enhance the welfare of society. In many African countries, the level of entrepreneurship is still low, limiting the growth of businesses and, therefore, stunting the private sector. It is notable in the literature that many of the small and medium enterprises on the continent never celebrate their first birthday. ${ }^{12}$ Business leaders need entrepreneurial skills and a supportive environment to create and manage sustainable business ventures, especially in developing economies. ${ }^{13}$

The continent lacks gender diversity in business leadership and management, as well as in the workforce, which significantly affects economic performance and sustainability. In their study, Augustine et al. ${ }^{14}$ examined the relationship between gender diversity within the workforce and the sustainability of economic performance in the microfinance industry in Africa. They reported that 'gender inequality in Africa's labour market overwhelmingly confines women to low-paid, insecure jobs and limited career paths' (p. 228). This illustrates another serious gap in the management of businesses on the continent, limiting productivity and inhibiting the private sector. Gender inequality in African business could be attributed to a dominant and slowly changing patriarchal culture on the continent. The authors argue that managers of the 21st century need to be empowered in order to ensure female participation in the workforce, as well as in leadership and management of businesses, as gender diversity promotes sustainable business ventures and firm performance. This assertion is supported by Tom Peters ${ }^{15}$ who indicated, based on his studies, that women have the skills and competencies that the organisations of the 21st century need to succeed.

Empowering global leaders is not complete without information and communications technology (ICT), especially in developing countries. African economies, coupled with infrastructural limitations, can ably make use of ICT not only to communicate and access information but also to develop and expand their production by introducing new products and services. Ponelis et al. ${ }^{16}$ indicated that adoption of ICT offers an array of opportunities and delivery systems that can increase the size, quality and variety of output for customers. This implies that African business leaders need to be empowered in the use of ICT to support their businesses and expand their operations, given the limited infrastructure and the absence of institutions that support efficient marketing of products and services. This will significantly lead to sustainable businesses, especially in the global south. 


\section{Research design and methodology Design and approach}

Researchers adopted a mixed-methods approach combining quantitative and qualitative data collection methods to identify the determinants of leadership in Africa. This approach was adopted because of the versatility it provides for investigating the research problem from diverse points of view, giving a deeper understanding of leadership deficits. The approach was used based on a recent systematic review calling for increased application of mixed-methods designs in educational leadership and management research in Africa. ${ }^{17}$ In order to ensure a collection of valid, reliable and quantitative data, a cross-sectional survey was used. The survey questionnaire consisted of 12 Likert-type questions that probed what the participants perceived as the most important determinants to leadership. Before the final distribution, the survey was piloted upon and discussed with a convenience sample of relevant respondents. Focus groups were adopted to gain more in-depth insights into possible determinants and to encourage reflections on the experiences of the participants as leaders. The discussion guide for focus groups was piloted and discussed in the research team, and then revised on the basis of the pilot results. The participants in the focus groups were asked to reflect upon and generate statements to the presented questions.

\section{Sample size and sampling techniques}

The researchers used the Krejcie et al. ${ }^{18}$ table to determine the sample size. Simple random sampling was used to select respondents for the survey, whilst purposive sampling was used to select participants for the focus group discussions (FGDs).

\section{Data analysis}

Survey data were entered into an Excel sheet and later transferred to Statistical Package for the Social Sciences (SPSS) software for analysis. The researchers analysed the data using descriptive statistics. Qualitative data were analysed by thematic analysis and later triangulated with the findings from the survey data.

\section{Key findings}

\section{Demographics and characteristics of study participants}

With respect to gender, $39.34 \%$ of participants were women, whilst $60.66 \%$ were men (see Figure 2).

It also revealed that $37.70 \%$ were between the ages of 26 and 35 years and $43.03 \%$ were between the ages of 36 and 45 years, with a significant small percentage of participants being younger or older than the two mentioned age groups (see Figure 3).

Both the gender and age ratio were in line with Zambian leadership demographics.
With respect to education level, the large majority of survey participants had at least an undergraduate degree $(20.58 \%)$, with some having graduate $(49.38 \%)$ and postgraduate $(29.63 \%)$ education (see Figure 4$)$.

The findings indicate that 246 Zambian leaders participated in the survey across 18 different industries, including $25.71 \%$ from the government, $11.45 \%$ from the business sector, $9.39 \%$ from the agriculture sector and $4.90 \%$ from the mining industry (see Figure 5).

With respect to the experience of respondents in leadership, the clear majority of leaders were relatively new in their roles, with $45.90 \%$ of leaders having $1-5$ years and $29.10 \%$ having 6-10 years of leadership experience (which correlates with the young age of surveyed leaders). About $45.87 \%$ of leaders managed fewer than 10 employees. About $42.45 \%$ of leaders had some global leadership experience, and 54.69\% of participants had no leadership experience, with a small percentage having extensive global leadership experience (see Figure 6).

In summary, on average, the survey participants were younger, highly educated women and men, representing a variety of Zambian industry sectors. About $45.68 \%$ of participants had 1-5 years of leadership experience, and almost $30 \%$ had 6-10 years of leadership experience (see Figure 6).

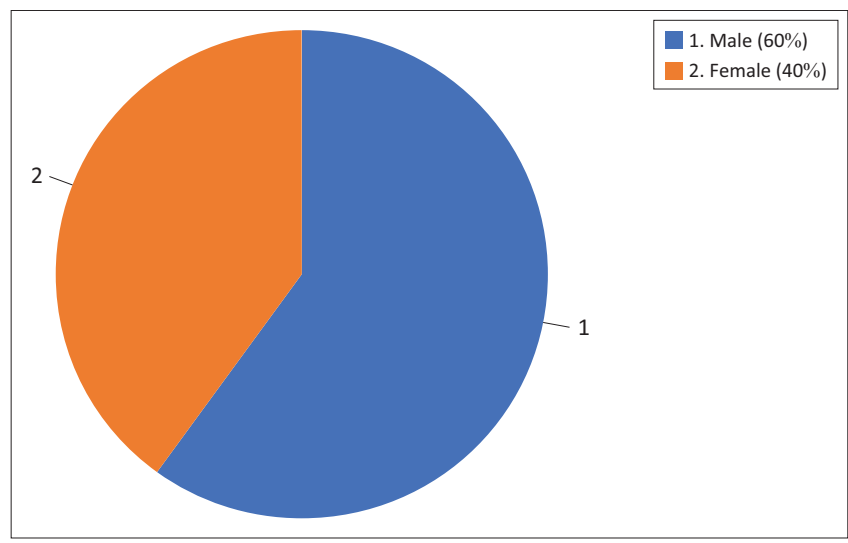

FIGURE 2: Gender distribution of study participants.

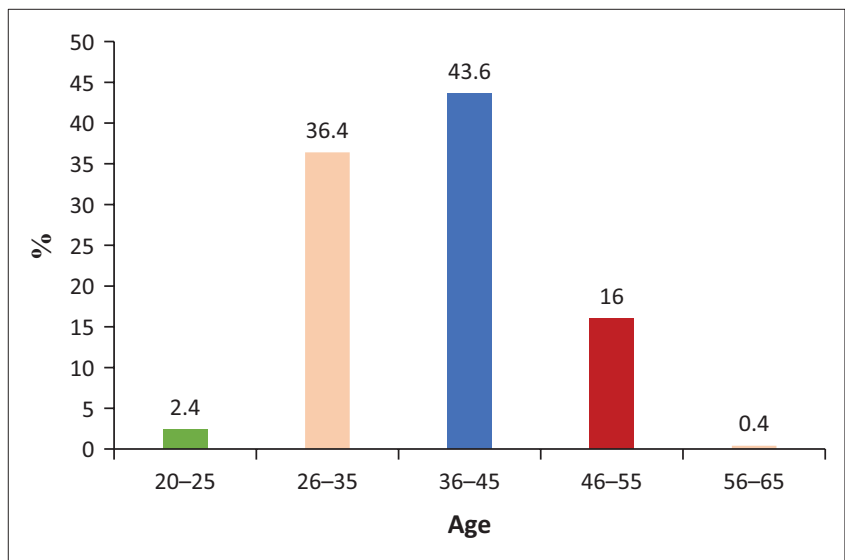

FIGURE 3: Age distribution of study respondents. 
Cross-tabulation between gender and education variables and gender and experience in leadership position variables is presented in Tables 1 and 2.

Some global experiences were reported by $42.62 \%$ of participants, which was cross-tabulated with the overall leadership experience in Table 3.

Participants were asked to share their views and perspectives regarding strategies that can be adopted to

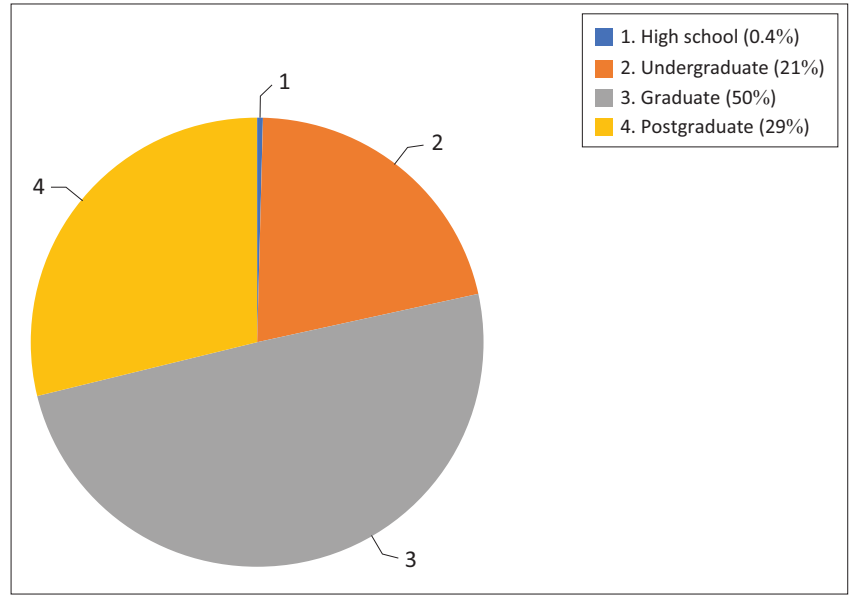

FIGURE 4: Education level of study participants.

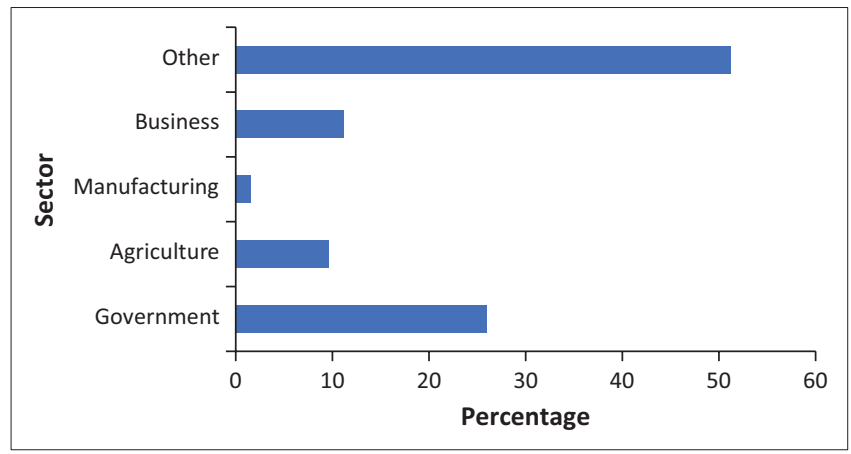

FIGURE 5: Sectors in which participants work. offset leadership gaps in their sectors and the country at large. The findings revealed that two variables that were deemed as the most important in offsetting leadership gaps were education and talent management at $36.59 \%$ and $35.77 \%$, respectively (see Figure 7).

As far as offsetting the leadership gap is concerned, education and talent management were deemed to be the most significant, with each noted by $36 \%$ of participants (see Figure 8).

The findings also revealed that amongst the resources, African leadership was lacking, technology was a leading variable at $23.97 \%$, followed by educational and financial resources at $17.36 \%$ and $16.94 \%$, respectively. Lack of natural resources was not deemed to be significant by $55 \%$ participants, which is aligned with the consensus of the focus group participants (see Figure 8 for findings on resource gaps).

In terms of missing resources, human resource management was deemed to be the most significant at $25 \%$, with

TABLE 1: Gender level of education cross-tabulation.

\begin{tabular}{|c|c|c|c|c|c|}
\hline \multirow[t]{2}{*}{ Count } & \multicolumn{4}{|c|}{ Level of education } & \multirow[t]{2}{*}{ Total } \\
\hline & High school & Undergraduate & Graduate & Postgraduate & \\
\hline \multicolumn{6}{|l|}{ Gender } \\
\hline Male & 1 & 27 & 68 & 52 & 148 \\
\hline Female & 0 & 25 & 54 & 18 & 97 \\
\hline Total & 1 & 52 & 122 & 70 & 245 \\
\hline
\end{tabular}

TABLE 2: Gender experience in a leadership position cross-tabulation.

\begin{tabular}{lcccccc}
\hline Count & \multicolumn{5}{c}{ Experience in a leadership position } & Total \\
\cline { 2 - 6 } & $\begin{array}{c}\text { Less than } \\
\text { a year }\end{array}$ & $\mathbf{1 - 5}$ years & $\mathbf{6 - 1 0}$ years & $\mathbf{1 1 - 1 5}$ years & $\begin{array}{c}\mathbf{1 5} \text { or more } \\
\text { years }\end{array}$ & \\
\hline Gender & & & & & & \\
Male & 5 & 64 & 43 & 28 & 9 & 149 \\
Female & 13 & 48 & 28 & 5 & 4 & 98 \\
\hline Total & $\mathbf{1 8}$ & $\mathbf{1 1 2}$ & $\mathbf{7 1}$ & $\mathbf{3 3}$ & $\mathbf{1 3}$ & $\mathbf{2 4 7}$
\end{tabular}

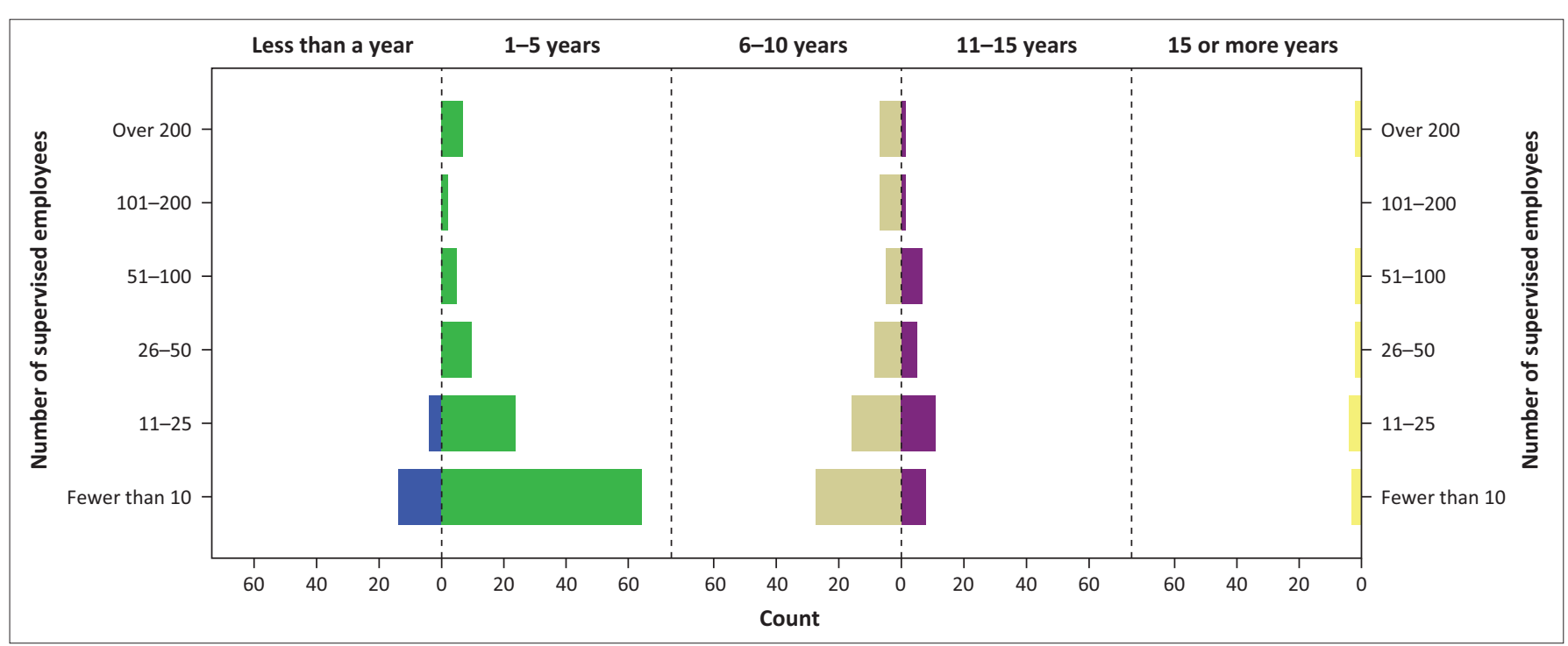

FIGURE 6: Experience of participants in a leadership position. 
TABLE 3: Experience in a leadership position global experience crosstabulation.

\begin{tabular}{lccccc}
\hline Count & Variable & \multicolumn{3}{c}{ Global experience } & Total \\
\cline { 3 - 5 } & & None & $\begin{array}{c}\text { Some } \\
\text { experience }\end{array}$ & Experienced & \\
\hline $\begin{array}{l}\text { Experience in a } \\
\text { leadership position } \\
\text { (years) }\end{array}$ & $\begin{array}{c}\text { Less than } \\
\text { a year }\end{array}$ & 16 & 2 & 0 & 18 \\
& $1-5$ & 74 & 38 & 1 & 113 \\
& $6-10$ & 29 & 39 & 3 & 71 \\
& $11-15$ & 15 & 16 & 2 & 33 \\
& 15 or & 3 & 9 & 1 & 13 \\
\hline more & - & $\mathbf{1 3 7}$ & $\mathbf{1 0 4}$ & $\mathbf{7}$ & $\mathbf{2 4 8}$ \\
\hline
\end{tabular}

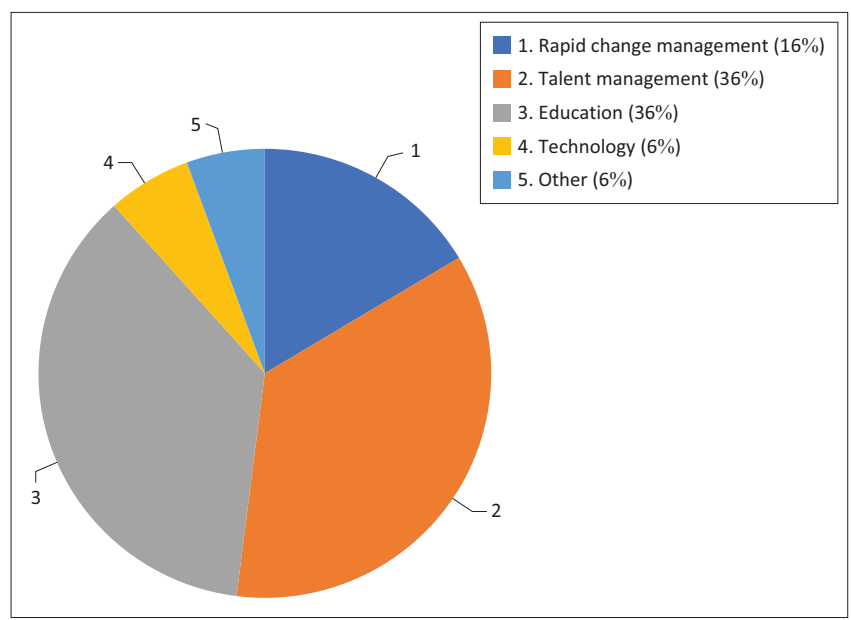

FIGURE 7: Proposed strategies for offsetting leadership gaps.

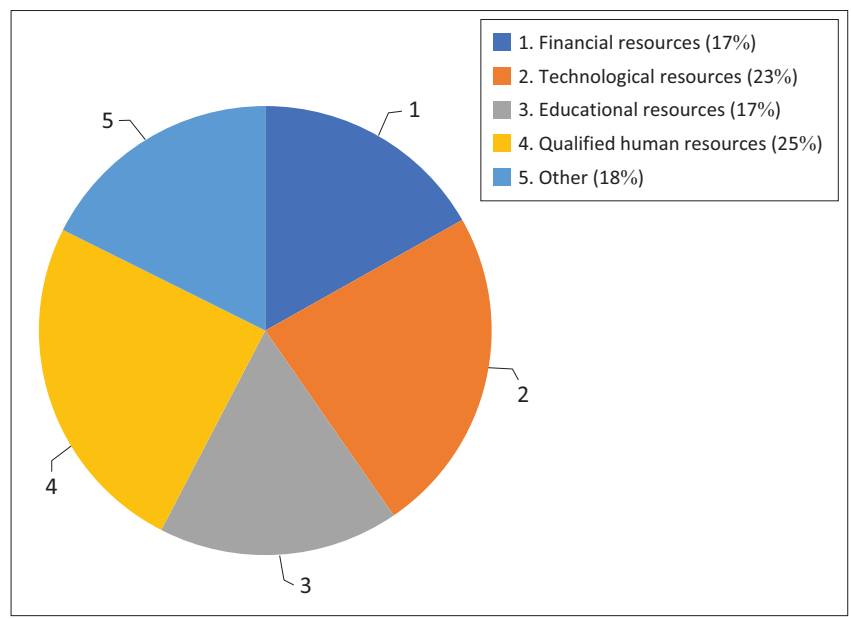

FIGURE 8: Resource gaps for African leaders.

technological resources following at $23 \%$ and financial and educational resources both at 17\% (see Figure 8).

Similar findings can be observed when it comes to the lack of talent, with $53 \%$ of participants dismissing that as an impactful variable. Leaders' empowerment and finding a unique African path of leadership were deemed to be significant by more than $70 \%$ of participants in each category. Over $50 \%$ of participants defined African leadership in terms of its traditionalist stance. The multigenerational workforce and women's path to leadership is defined as challenging by almost $50 \%$ of participants (see Table 4).
TABLE 4: Likert-scale responses on challenges for African leaders.

\begin{tabular}{|c|c|c|}
\hline Variable & Response & $\%$ \\
\hline \multirow{3}{*}{$\begin{array}{l}\text { Need for equipment with } \\
\text { knowledge and skills }\end{array}$} & Strongly agree/agree & 79 \\
\hline & Neither agree or disagree & 11 \\
\hline & Disagree/strongly disagree & 10 \\
\hline \multirow{3}{*}{$\begin{array}{l}\text { Unique challenges for African } \\
\text { leaders }\end{array}$} & Strongly agree/agree & 63 \\
\hline & Neither agree or disagree & 14 \\
\hline & Disagree/strongly disagree & 23 \\
\hline \multirow{3}{*}{$\begin{array}{l}\text { Lack of resources is the biggest } \\
\text { challenge for Zambian leaders }\end{array}$} & Strongly agree/agree & 32 \\
\hline & Neither agree or disagree & 13 \\
\hline & Disagree/strongly disagree & 55 \\
\hline \multirow{3}{*}{$\begin{array}{l}\text { Lack of talent is the biggest } \\
\text { challenge for Zambian leaders }\end{array}$} & Strongly agree/agree & 34 \\
\hline & Neither agree nor disagree & 14 \\
\hline & Disagree/strongly disagree & 53 \\
\hline \multirow{3}{*}{$\begin{array}{l}\text { Poor infrastructure is the biggest } \\
\text { challenge for Zambian leaders }\end{array}$} & Strongly agree/agree & 47 \\
\hline & Neither agree nor disagree & 18 \\
\hline & Disagree/strongly disagree & 35 \\
\hline \multirow{3}{*}{$\begin{array}{l}\text { Zambian leaders are capable of } \\
\text { overcoming the challenges faced }\end{array}$} & Strongly agree/agree & 73 \\
\hline & Neither agree nor disagree & 10 \\
\hline & Disagree/strongly disagree & 17 \\
\hline \multirow{3}{*}{$\begin{array}{l}\text { Managing multigenerational } \\
\text { workforce is a challenge }\end{array}$} & Strongly agree/agree & 47 \\
\hline & Neither agree nor disagree & 26 \\
\hline & Disagree/strongly disagree & 28 \\
\hline \multirow{3}{*}{$\begin{array}{l}\text { African leadership style is too } \\
\text { traditional }\end{array}$} & Strongly agree/agree & 53 \\
\hline & Neither agree nor disagree & 14 \\
\hline & Disagree/strongly disagree & 33 \\
\hline \multirow{3}{*}{$\begin{array}{l}\text { It is more difficult for women to } \\
\text { become leaders }\end{array}$} & Strongly agree/agree & 47 \\
\hline & Neither agree nor disagree & 12 \\
\hline & Disagree/strongly disagree & 40 \\
\hline \multirow{3}{*}{$\begin{array}{l}\text { It is more difficult for women to } \\
\text { establish their authority }\end{array}$} & Strongly agree/agree & 52 \\
\hline & Neither agree nor disagree & 11 \\
\hline & Disagree/strongly disagree & 38 \\
\hline \multirow{3}{*}{$\begin{array}{l}\text { African leaders need to develop } \\
\text { their own path of leadership }\end{array}$} & Strongly agree/agree & 74 \\
\hline & Neither agree nor disagree & 11 \\
\hline & Disagree/strongly disagree & 15 \\
\hline \multirow{3}{*}{$\begin{array}{l}\text { Should empowering leaders be a } \\
\text { key goal? }\end{array}$} & Strongly agree/agree & 78 \\
\hline & Neither agree nor disagree & 11 \\
\hline & Disagree/strongly disagree & 11 \\
\hline
\end{tabular}

An overwhelming majority of survey participants agreed that African leaders face a unique set of challenges in comparison with their Western counterparts; lack of proper talent management and poor infrastructure were noted as two of the leading variables. Similarly, most of the participants felt that African and Zambian leaders need to pursue their own unique path of leadership rather than pursuing a 'copy/paste' approach of observing some other leadership styles.

Based on the survey findings and leadership seminar group activities, the findings show that despite the record growth rates, the African region faces a multitude of issues in the areas of infrastructure; resource curse; human resources; and talent management, mentoring and training.

Survey participants found that the clear majority of resources need to be invested in talent management, education, empowering female leaders and finding a unique African leadership path in order to ensure that Zambian leadership is sustainable in the global economy and equipped with skills needed in the 21st century. 


\section{Qualitative findings}

The FGDs were conducted at each seminar, which included 50 (each session) middle- to high-ranking Zambian leaders who were attendees from 18 different industries. Seminar participants completed a group activity, and found the following themes and patterns that Zambian leaders need to focus on: integrity of leaders, effective leadership education, proper management of resources, knowledge management specific for the southern African region and proper financial management. Others were development of critical thinking, accountability and adaptation skills, newer meaningful technology that enhances business bottom line, and clear vision for both their enterprise and their country. The deficiency in these skills could be the inability to practise and infuse the RARE values in the modus operandi of the leaders and managers. During one of the FGDs, some of the participants argued:

'A number of things are lacking; Critical thinking is one of the aspects that is lacking. I think most schools (both undergraduate and postgraduate) do not address this aspect fully. Another challenge is the lack of objectivity in judgement. This comes as a result of the cultural influence on most Zambian leaders. There is a need to separate the individual's private life from life at work, which most leaders fail to do. This is lacking in most leaders leading to selecting wrong people for certain jobs without a critical review of performance. Patronage when appointing people to critical positions or when making critical decisions is affecting leadership negatively.' (FGD, Participant C)

'What I think is lacking is visionary leaders who are committed to public service and have a discipline to identify and curb corruption at its highest form. Then also bridging the leadership gap between the old and young. In terms of solutions, I think we need thought leaders who are visionaries to be put in sensitive offices for they will have the power to set the tone of how we should run as a Country.' (FGD, Participant F)

'Our leaders lack discipline with regard to the management of available resources to achieve sustainable development. This is evident in many African countries where corruption is reported on a daily basis. Possible solutions to these challenges include: utilize within the means of the country to avoid massive borrowing and empower the younger generation to lead higher offices or start up businesses which the govt can promote.' (FGD, Participant A)

One of the participants, however, reported that Zambia has many talents to provide good leadership but the system of recruitment and placement in the position of responsibility is not based on merit. One participant had this to say:

'Zambia has enough talent to provide good leadership but unfortunately most leadership positions are not given on merit but instead based on political affiliation. We have people who can contribute to solving most of our problems but such people are not offered these positions because they do not belong to certain political groups and cannot obtain favour. If we could only be more professional in our recruitments and embrace people who have a lot to offer, we would be on our way to attaining this sustainable development.' (FGD, Participant L)
The issues of poor working environment and political culture, as well as overstaying in power, were evidently mentioned by some participants in the FGDs. One of the participants reported that:

'The main items lacking in leadership for sustainable development are: (1) many African leaders do not allow a culture where people can operate independently and make decisions; (2) the need to groom successors. Most African leaders would like to lead till their death bed without grooming a successor; and (3) the need to adjust and adapt to new ways of doing things in the global village. Most leaders prefer to do things generation after generation. They are not open to new ideas provided the traditional ways keep bearing fruits. This has led to serious directional challenges for most organizations.' (FGD, Participant K)

Focus group participants were asked to share their views and participants regarding what needs to be performed to promote transformative leadership and workplace sustainability. Many of them recommended a review of the education system, improvement of communication and working environment, as well as promotion of local solutions and innovation. Some of them said:

'There is a need to ensure that the educational system drives a mindset that seeks to change society rather than conform. The educational system does not encourage a more thinking process but rather a more memorising mindset. Therefore, we find less entrepreneur mindset that think outside the box and are not limited by socialisation constraints of being puppets who do not stray or question the status quo. There is more of a selfish drive without consideration of how leadership will impact society as a whole.' (FGD, Participant K)

'I think leaders need to look for solutions first in their surroundings, be more transparent and communicative with their employees in finding possible solutions, rely on their team, and should does not underestimate them, but improve communication.' (FGD, Participant E)

'I think we should shift away from a centralised approach to engaging and empowering local systems and leverage financial service innovations.' (FGD, Participant C)

From a sustainability lens, some participants called for integration of ecological issues in development and business management. One of the FGD participants stated:

'What is lacking is the missing link between profit making and conservation of the environment or the ecological and social aspects in the management of the organisations. Leaders pay more attention on how to maximize the profit. The possible solution is to orient managers on how to manage their organisations taking into account of the organisations' impacts or effects on the environment and the social part. To take a holistic approach to minimise damage on any of the three spheres. Damage to the environment can be reduced by incorporating or use of technology in the operations of the institution. Also on the social aspect to consider the community and employees' needs instead of concentrating on getting profits.' (FGD, Participant B)

Some participants called for creation of awareness on sustainable development issues amongst leaders and the 
need to consider diverse cultural workforce across sectors, as well as on promotion of RARE values amongst leaders. One of them suggested:

'To start with, political, traditional and the corporate world leaders need to understand what sustainable development is (development that meets the needs of the current generation without compromising the needs of the future generation). Secondly, our leaders need to understand the importance of having a diverse cultural workforce and how to use diversity for productivity purpose and not for division. Thirdly, Zambian leaders need to have the RARE (Responsible, Accountable, Relevant, Ethical) values. Finally, the possible solution to leadership challenges in Zambia and in Africa at large is accountability, we need a board in Zambia and in Africa where our political leaders will be accountable to.' (FGD, Participant H)

\section{Limitations}

This study is limited to the data pool of Zambian leaders. To ensure significant findings in the entire southern African region, similar studies need to be conducted in the neighbouring countries. The clear majority of participants were in middle- to high-level leadership positions. Leaders in lower ranking leadership positions might have different perspectives. The male and young leaders were overrepresented in the data pool, but this reflects the current demographics of Zambian leadership.

\section{Conclusion}

The landscape of African leadership is changing. African emerging markets, changing demographics, disruptive technology integration and global political environment are shaping a new brand of African leaders. Zambian leaders realise that isolating themselves is not a winning strategy in the long run. However, opening to global opportunities does not entail allowing Zambia to be taken advantage of, as was the case in the past. The luxury of African leadership is that it does not have to be slowly evolving but can 'skip some steps' taking advantage of the lessons learnt in the West. The survey and focus group participants expressed optimism when it comes to Zambian leaders being able to pursue their unique path of leadership creating political, economic and social structures, which will take advantage of Zambian natural and human resources in order to enhance Zambian development and growth. The research community might need to explore the underlying sociocultural factors that affect women leadership on the continent. There is a need to explore initiatives that are effective in dealing with leadership deficits on the continent, as well as opportunities for the business leaders in the Global North to effectively work with those of the Global South. There is also a need for research into how African indigenous knowledge and value systems, such as RARE values, can be exploited to support the development of effective leadership on the continent as pursuit for global opportunities continues.

\section{Implications for policy and future research}

The findings of this study shed light on a number of policy issues that may require policy responses. These include the need for a review of the education systems to embed aspects of transformative leadership, especially at the university level; the need to ensure recruitment of business and other leaders is based on merit; and the need to incorporate sustainability issues in the workplace management culture and practices. There are other policy implications at various levels with respect to promotion of gender and women empowerment for transformative leadership across sectors. These findings might be useful for policymakers at national and organisational levels.

To ensure relevance and applicability of findings in other southern African regions, researchers suggest similar studies to be conducted in several neighbouring countries: South Africa, Angola, Botswana, Lesotho, Mozambique, Namibia, South Africa, Swaziland and Zimbabwe. The data pool can be expanded to include more women leaders and junior-level leadership to see whether the findings would significantly change. The focus groups can also be conducted in a corporate versus seminar-type setting to avoid the logistical complexity of a Fulbright seminar and to gather more samples.

\section{Acknowledgements}

The authors acknowledge the financial support from the Fulbright Program.

\section{Competing interests}

The authors have declared that no competing interest exists.

\section{Authors' contributions}

All authors contributed equally to this work.

\section{Ethical consideration}

The researchers ensured ethical research practice in undertaking the study. Participants were given all the information about the study and asked to consent in writing before participating in the study. To ensure confidentiality, the researchers anonymised all participant names and ensured privacy. The study protocols and tools were subjected to ethical review at Mulungushi University in Zambia.

\section{Funding information}

This study received funding from the Fulbright Program.

\section{Data availability statement}

Data are available for sharing on request from the authors. 


\section{Disclaimer}

The views and opinions expressed in this article are those of the authors and do not necessarily reflect the official policy or position of any affiliated agency of the authors.

\section{References}

1. The Dean of Duke Fuqua looks specifically for candidates with triple threat capabilities that don't come naturally to everyone [homepage on the Internet] Business Insider India; 2018 [cited 2020 May 17]. Available from: https://www. businessinsider.in

2. Riva-Mossman S, Kampel T, Cohen C, Verloo H. The senior living lab: An example of nursing leadership. Clin Interv Aging. 2016;11:255-263. https://doi. of nursing leadership.

3. Abazeed RAM. Impact of transformational leadership style on organizational learning in the Ministry of communication and information technology in Jordan. Int J Bus Soc Sci. 2018;9(1):118-129.

4. Ngambi HC. Advancing the developmental goals of Africa through RARE and total leadership: The case of Thabo Mbeki. In: Pityana NB, editor. Building blocks towards an African century: Essays in honor of Thabo Mbeki, Former President of the Republic of South Africa. Johannesburg: Real African Publishers; 2018.

5. Acquaah $\mathrm{M}$, Zoogah $\mathrm{DB}$, Kwesiga EN. Advancing Africa through managemen knowledge and practice: The way forward. Adv J Econ Manag Stud. 2013;4(2):164-176. https://doi.org/10.1108/AJEMS-04-2013-0036

6. Donkor F, Dongmei Z. Leadership styles: A decade after economic recession and lessons for businesses in developing economies. Manag Res Pract. 2018;10(3):5-23.

7. George G, Corbishley C, Khayesi JNO, Haas MR, Tihanyi L. Bringing Africa in: Promising directions for management research. Acad Manag $J$. 2016;59(2):377-393. https://doi.org/10.5465/amj.2016.4002
8. Ngambi HC. RARE leadership: An alternative leadership approach for Africa. Int Afr Renaissance Stud Multi Inter Transdisciplinarity. 2011;6(1):6-23. https://doi. org/10.1080/18186874.2011.592387

9. Olalere A. Complexity and leadership crisis in Africa. Int J Publ Leader. 2015;11(3/4):180-191. https://doi.org/10.1108/IJPL-08-2015-0021

10. Nkomo SM. A postcolonial and anti-colonial reading of African leadership and management in organization studies: Tensions, contradictions and possibilities. Organ. 2011;18(3):365-386. https://doi.org/10.1177/135050 8411398731

11. Donaldson WJ, Pauceanu AM. Marketing challenges for South African public sector business Incubator. J Competitiveness. 2017;9(4):19-39. https://doi. org $/ 10.7441 /$ joc.2017.04.02

12. Isidahomen EO. Why African small businesses fail: How to prevent early SME deaths [homepage on the Internet]. Business Africa, Feature, Finance and Investment, Our Picks; 2019. Available from: www. businesselitesafrica.com

13. Fatoki O. The causes of the failure of new small and medium enterprises in South Africa. Mediterr J Soc Sci. 2014;5(20):922. https://doi.org/10.5901/mjss.2014 v5n20p922

14. Augustine D, Baraldi M, Wheat CO, Malgwi CA, Jones KS. Gender diversity within the workforce in the microfinance industry in Africa: Economic Performance and Sustainability. Can J Adm Sci. 2016;33(3):227-241. https://doi.org/10.1002/ cjas.1365

15. Peters T. Re-imagine. New York, NY: DK Publishing; 2003.

16. Ponelis SR, Holmner MA. ICT in Africa: Building a better life for all. Inf Technol Dev. 2015;21(2):163-177. https://doi.org/10.1080/02681102.2015.1010307

17. Hallinger P. A systematic review of research on educational leadership and management in South Africa: mapping knowledge production in a developing society. International Journal of leadership in education. 2019;22(3):315-333.

18. Krejcie R.V. and Morgan D.W. Determining Sample Size for Research Activities. Educational and Psychological Measurement. 1970;(30):607-610 